\title{
A Flow Reaction System Using Catalytic Magnetic Particles
}

Immobilization of catalyst on magnetic particles:<smiles>NC(=O)OC(=O)c1cccc(C(=O)Nc2ccccc2)n1</smiles>
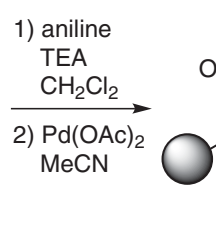<smiles></smiles>

catalyst particle 1

A fluidic system:

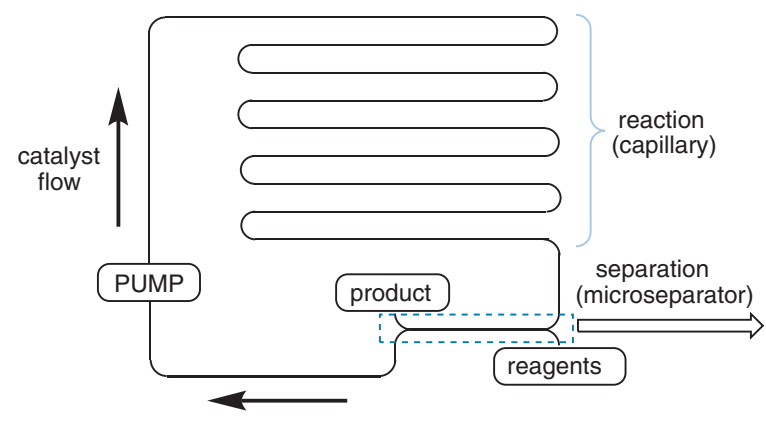

Microseparator:

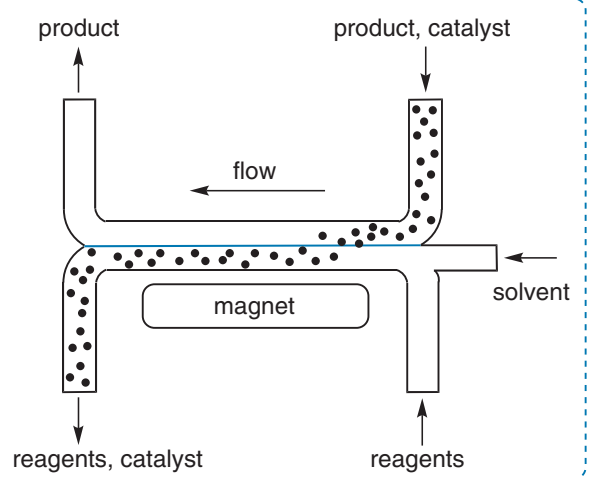

-: catalyst particle 1

Dioxygenation of alkenes in the fluidic system:

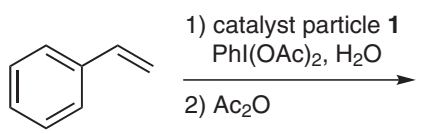<smiles>CC(=O)OCC(OC(C)=O)c1ccccc1</smiles><smiles>C=CCC#N</smiles>

1) catalyst particle 1 $\mathrm{Phl}(\mathrm{OAc})_{2}, \mathrm{H}_{2} \mathrm{O}$

2) $\mathrm{Ac}_{2} \mathrm{O}$
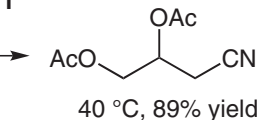<smiles>C1=C(c2ccccc2)CCCC1</smiles>

1) catalyst particle 1 $\mathrm{Phl}(\mathrm{OAc})_{2}, \mathrm{H}_{2} \mathrm{O}$

2) $\mathrm{Ac}_{2} \mathrm{O}$<smiles>CC(=O)OC1CCCCC1(O)c1ccccc1</smiles>

Key words

magnetic particles

microseparator chip

capillary

microtubes

flow chemistry
Significance: A novel fluidic system using catalytic magnetic particles was developed. In the separator part (microseparator), the product stream with the catalytic magnetic particles merged with the solvent stream, and the particles in the product stream moved into the solvent stream with the aid of the external magnetic field. Almost no mixing and thus, almost complete separation occurred as a result of laminar flow. The dioxygenation of alkenes was carried out in the fluidic system using catalyst particle 1 (4 examples, 83-89\% yield).

sYNFACTS Contributors: Yasuhiro Uozumi, Yoichi M. A. Yamada, Maki Minakawa Synfacts 2010, 12, 1431-1431 Published online: 22.11.2010 DOI: 10.1055/s-0030-1258910; Reg-No.: Y12110SF
Comment: The flow system consists of a microfluidic chip type of a microseparator [poly(dimethylsiloxane): width: $300 \mu \mathrm{m}$, depth: $50 \mu \mathrm{m}$, length: $20 \mathrm{~mm}$ ] and a capillary microtube reactor [poly(tetrafluoroethylene): diameter: $500 \mu \mathrm{m}$, length: $260 \mathrm{~cm}$. In the preparation of magnetic catalyst $\mathbf{1}$, commercially available magnetic particles having silica surface functionalized with primary amine groups were used (average size: $1.99 \mathrm{~mm}$, AccuBead, bioneer, Korea). 